\title{
Lama Hari Rawat Pasien Stroke
}

\author{
Novita Nirmalasari $^{1 *}$, Muhamat Nofiyanto ${ }^{2}$, Rizqi Wahyu Hidayati ${ }^{3}$ \\ ${ }^{1,2,3}$ Fakultas Kesehatan, Universitas Jenderal Achmad Yani Yogyakarta \\ *Email: novitanirmalasari@gmail.com
}

\begin{abstract}
Background: Stroke has remained the leading cause of death globally in the last 15 years. Stroke is rapidly developing clinical signs of focal or global disturbance of cerebral function. Hospitalization is a treatment process which including patient to stay at the hospital. Length of stay is influenced by the type of stroke. This study aimed to know classification of stroke and length of stay of stroke patients. Methods: The study was a descriptive study with restrospective design. Data collected from medical record from May until December 2020 in RS PKU Muhammadiyah Yogyakarta. There were 207 patients with stroke. Descriptive data is then processed. Results: The results showed the highest percentage stroke patients male (50,24\%), non hemorrhagic stroke (57,49\%), length of stay hemorrhagic stroke 8 days. Conclusion: The result of this study may provide nursing research in patients with stroke.
\end{abstract}

Keywords : length of stay, stroke, type stroke

\section{PENDAHULUAN}

Stroke menjadi penyebab utama kematian secara global dalam 15 tahun terakhir (WHO, 2012). Data Riset Kesehatan Dasar menyebutkan bahwa prevalensi stroke berdasarkan diagnosis dokter tahun 2018 sebanyak 10,9\% di Indonesia. Daerah Istimewa Yogyakarta merupakan provinsi tertinggi penderita stroke pada penduduk berusia lebih dari 15 tahun dengan jumlah 14,7\% (Kemenkes RI, 2018)

Stroke merupakan gangguan disfungsi neuroligis akut yang terjadi secara mendadak dengan gejala dan tanda yang sesuai dengan daerah fokal otak yang terganggu. Data menunjukkan bahwa kejadian stroke merupakan serangan stroke pertama kali. Faktor resiko stroke salah satunya adalah hipertensi. Hasil penelitian menunjukkan bahwa seseorang dengan hipertensi meningkatkan resiko 3,8 kali terkena stroke (Sorganvi et al., 2014). Penelitian lain juga menunjukkan bahwa seseorang dengan tekanan darah sistolik $\geq 140$ mmHg mempunyai resiko 5,12 kali untuk terserang stroke, dan diastolik $\geq 90 \mathrm{mmHg}$ lebih besar terkena stroke iskemik. Penanganan stroke yang tepat akan meningkatkan kualitas hidup pasien stroke (Darmanto, 2014).

Faktor-faktor lain yang dapat. Hal ini antara lain jenis kelamin dan hipertensi. Prevalensi stroke sering dijumpai pada laki-laki dibandingkan dengan wanita pada usia dewasa awal karena hormone testoteron dan estrogen yang dimiliki. Hipertensi salah satu faktor resiko yang meningkatkan terjadinya stroke sebanyak 6 kali lipat (Laily, 2017).

Stroke ada dua jenis yaitu stroke iskemik atau non hemoragik dan stroke hemoragik. Stroke non hemoragik sebagian besar merupakan komplikasi dari penyakit vaskular. Stroke hemoragik umumnya disebabkan oleh adanya perdarahan intracranial (Batticaca, 2008).

Jenis stroke merupakan salah satu faktor yang mempengaruhi lama rawat inap di rumah sakit dan menentukan kondisi akhir pasien saat keluar dari rumah sakit (Sulistyani \& Purhadi, 2013). Stroke hemoragik mempunyai tingkat 
kematian yang lebih tinggi, biaya perawatan kesehatan yang lebih tinggi dan lama rawat inap yang lebih lama (Curtain et al., 2017). Lama rawat inap merupakan indikator penting untuk menentukan keberhasilan terapi di rumah sakit dan beban biaya rawat inap. Keluarga dan pasien juga akan menimbulkan beban ekonomi yang cukup besar apabila semakin lama rawat inap yang diperlukan (Sulistyani \& Purhadi, 2013).

Berbagai penelitian yang berkaitan dengan stroke telah banyak dilakukan. Namun, penelitian tersebut belum ada yang membahas secara spesifik klasifikasi stroke dan lama rawat inap pasien stroke di rumah sakit PKU Muhammadiyah Yogyakarta. Penelitian ini diharapkan dapat memberikan informasi klasifikasi stroke dan lama rawat inap sehingga dapat menjadi dasar dalam upaya pencegahan pasien stroke. Tujuan penelitian adalah untuk mengetahui klasifikasi stroke dan lama rawat inap pasien stroke.

\section{METODE PENELITIAN}

Metode penelitian yang digunakan adalah deskriptif retrospektif. Peneliti mengambil data sekunder dari data rekam medis penderita stroke yang di rawat inap RS PKU Muhammadiyah Yogyakarta pada bulan Mei sampai Desember 2019. Jumlah penderita stroke sebanyak 212 orang. Sebanyak 5 orang tidak menjadi sampel penelitian karena diagnosa stroke yang tidak jelas sehingga jumlah sampel adalah 207 orang. Variabel tunggal pada penelitian ini adalah karakteristik pasien stroke yang dirawat inap. Pengumpulan data dilakukan dengan mencatat data dari rekam medis yang meliputi klasifikasi stroke dan lama rawat pasien stroke. Analisis data yang digunakan adalah deskriptif dalam bentuk distribusi frekuensi.

\section{HASIL PENELITIAN}

Penelitian dilakukan pada 207 pasien stroke yang dirawat inap di RS PKU Muhammadiyah Yogyakarta.

Tabel 1. Distribusi Pasien Stroke Berdasarkan Jenis Kelamin ( $\mathrm{n}=207)$

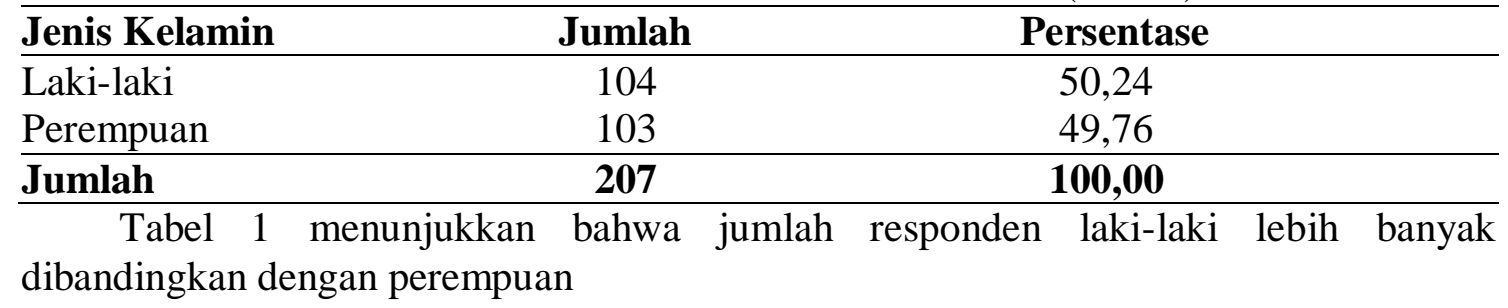

Tabel 2. Distribusi Pasien Stroke Berdasarkan Tipe Stroke dan Lama Rawat ( $n=207)$

\begin{tabular}{|c|c|c|}
\hline Tipe Stroke & Jumlah & Persentase \\
\hline Stroke hemoragik & 88 & 42,51 \\
\hline Stroke non hemoragik & 119 & 57,49 \\
\hline Jumlah & 207 & 100,00 \\
\hline
\end{tabular}


Tabel 3. Distribusi Pasien Stroke Berdasarkan Lama Rawat $(n=207)$

\begin{tabular}{lcccc}
\hline \multirow{2}{*}{ Klasifikasi Stroke } & \multicolumn{4}{c}{ Lama Rawat Inap (hari) } \\
\cline { 2 - 5 } & Jumlah & Min & Max & Mean \\
\hline Stroke hemoragik & 675 & 1 & 41 & 8 hari \\
Stroke non hemoragik & 842 & 1 & 17 & 7 hari \\
\hline
\end{tabular}

Jumlah 1517

Tabel 3 menunjukkan bahwa responden dengan stroke hemoragik mengalami rawat inap lebih lama dibandingkan dengan stroke non hemoragik.

\section{PEMBAHASAN}

Penelitian ini menunjukkan bahwa pasien stroke lebih banyak ditemukan pada pasien laki-laki dibandingkan perempuan. Penelitian lain juga menunjukkan mayoritas pasien stroke adalah laki-laki (Curtain et al., 2017). Hal ini sesuai dengan penelitian yang menunjukkan proporsi jenis kelamin paling dominan adalah laki-laki sebanyak 60\%. Hal ini disebabkan karena perempuan mempunyai hormon estrogen lebih banyak dibandingkan laki-laki sebelum masa menopause (Mahayani \& Putra, 2019). Penelitian ini sejalan dengan penelitian yang menunjukkan bahwa sebagian besar penderita stroke adalah laki-laki sebanyak 65\% (Yuwanda et al., 2020). Distribusi pasien dengan jenis kelamin laki-laki juga lebih besar dengan jumlah 162 orang $(55,29 \%)$ berdasarkan penelitian terdahulu (Amiman, Tumboimbela, \& Kembuan, 2016).

Penelitian sejalan memaparkan bahwa stroke iskemik pada laki-laki sejumlah 162 orang $(55,29 \%)$ lebih banyak jika dibandingkan perempuan yang hanya 131 orang $(44,71 \%$ ) (Amiman et al.,2016).Laki-laki memiliki hormone testosterone yang meningkatkan kadar LDL darah. Kadar LDL yang tinggi akan meningkatkan kadar kolesterol dalam

darah yang dapat menyebabkan penyakit degenatif. Perempuan memiliki risiko lebih rendah karena hormon estrogen yang dimiliki mampu mencegah proses aterosklerosis sampai usia menopause (Laily, 2017).

Hasil penelitian menunjukkan stroke non hemoragik lebih banyak diderita daripada stroke hemoragik. Penelitain serupa menunjukkan bahwa sebanyak $82,2 \%$ mengalami stroke iskemik dan $17,7 \%$ mengalami stroke hemoragik (Curtain et al., 2017). Penelitian lain juga mendapatkan hasil bahwa stroke iskemik lebih banyak diderita pada laki-laki yaitu $41,4 \%$ dibandingkan dengan stroke hemoragik yaitu 40,9\% (Atadzhanov et al., 2012). Penelitian lain memaparkan bahwa dari 88 responden, sejumlah $97,7 \%$ mengalami stroke iskemik dengan riwayat hipertensi. Hasil uji statistik didapatkan hasil $\mathrm{p}<0,05$, ada hubungan riwayat hipertensi dengan kejadian stroke iskemik. Hipertensi akan memicu adanya aterosklerosis yang meningkatkan risiko penyumbatan pembuluh darah menuju otak (Laily, 2017).

Hasil penelitian menunjukkan lama rawat inap pasien stroke hemoragik lebih lama jika dibandingkan dengan stroke non hemoragik. Penelitian menyebutkan bahwa pasien dengan stroke hemoragik memiliki lama rawat yang lebih lama dibandingkan dengan stroke non hemoragik. Hal ini dapat diperparah dengan faktor usia dan penyakit lain (Curtain et al., 2017). Penelitian ini sejalan d engan penelitian yang 
menunjukkan lama rawat inap pasien stroke hemoragik lebih lama dibandingkan dengan stroke non hemoragik. (Herminawati et al., 2008). Penelitian sebelumnya menunjukkan lama rawat pasien stroke hemoragik memiliki rata rata 11,04 hari, berbeda pada pasien stroke non hemoragik yang hanya memiliki ratarata 8,42 hari. Sejumlah 64 dari pasien stroke hemoragik memiliki faktor risiko hipertensi, sejumlah 18 orang memiliki faktor resiko dyslipidemia dan sejumlah 9 orang memiliki diabetes mellitus tipe II. (Amiman et al., 2016). Pasien stroke iskemik memiliki kemungkinan perbaikan laju klinis 2,46 kali lebih cepat dibandingkan stroke hemoragik. Hal ini mengakibatkan lama rawat inap yang lebih lama pada pasien stroke hemoragik (Sulistyani \& Purhadi, 2013).

Penelitian menunjukkan stroke hemoragik memilki faktor prediktor luaran klinik yang buruk. Stroke hemoragik juga memiliki faktor resko terjadinya komplikasi pada pasien stroke. Hal ini membuat pasien membutuhkan perawatan yang lebih lama. Perpanjangan lama rawat inap ini juga akan berdampak pada luaran klinik pasien yang buruk dengan timbulnya komplikasi lain seperti decubitus (Pinzon \& Hardjito, 2017).

Penelitian lain menunjukkan bahwa 98,3\% tidak mengetahui kegawatan stroke yang mereka alami sehingga menunda untuk datang ke rumah sakit lebih dari 4 jam. Hal ini akan memperparah kondisi stroke sehingga meningkatkan perawatan stroke lebih lama (Tangkudung et al., 2019). Penelitian lain juga menunjukan bahwa rata rata pasien stroke iskemik mempunyai lama rawat inap 2-6 hari sebesar $70 \%$ dan lebih dari 6 hari sebanyak $5,6 \%$. Sehingga $75 \%$ pasien yang dirawat dengan stroke iskemik mempunyai lama rawat inap lebih dari 2 hari (Qureshi et al, 2013). Sejumlah $58,2 \%$ pasien stroke memiliki lama rawat inap kurang dari 8 hari dan 41,8\% lebih dari 8 hari (Saxena \& Prasad, 2016).

\section{KESIMPULAN DAN SARAN}

Dapat disimpulkan bahwa lama rawat inap pasien stroke hemoragik lebih lama jika dibandingkan dengan stroke non hemoragik. Pasien stroke non hemoragik akan dirawat selama 1-17 hari, dengan rata-rata 7 hari, sedangkan pasien stroke hemoragik dirawat dalam waktu 1-41 hari, dengan rata-rata 8 hari. Stroke hemoragik memberikan gejala yang lebih berat dari stroke non hemoragik.

Hasil penelitian dapat menjadi dasar dalam mengembangkan penelitian keperawatan khususnya klasifikasi dan lama rawat inap pasien stroke. Penelitian lebih lanjut bisa dilakukan dengan waktu yang lebih lama dan karakteristik yang lebih banyak sehingga hasil penelitian lebih baik. Upaya pencegahan stroke hemoragik perlu ditingkatkan.

\section{DAFTAR RUJUKAN}

Amiman, R. C., Tumboimbela, M. J., \& Kembuan, M. A. H. N. (2016). Gambaran length of stay pada pasien stroke rawat inap di RSUP Prof. Dr. R. D. Kandou Manado periode Juli 2015-Juni 2016. ECliniC,4(2).https://doi.org/10.35790 /ecl.4.2.2016.14500

Atadzhanov, M. (2012). Stroke Characteristics and Outcomes of Adult Patients Admitted to the University Teaching Hospital, Lusaka, Zambia. The Open General and Internal Medicine Journal, 5(1), 3-8. 
https://doi.org/10.2174/1874076601 205010003

Batticaca, F. B. (2008). Asuhan Keperawatan pada Klien dengan Gangguan Sistem Persyarafan. Jakarta: Salemba Medika.

Curtain, J. P., Yu, M., Clark, A. B., Gollop, N. D., Bettencourt-Silva, J. H., Metcalf, A. K., Myint, P. K. (2017). Determinants of length of stay following total anterior circulatory stroke. Geriatrics (Switzerland), 2(3), 19.https://doi.org/10.3390/geriatrics2 030026

Darmanto, A. (2014). Hubungan Antara Hipertensi dengan Kejadian Stroke Iskemik di Bangsal dan Poliklinik Saraf RSUD Dr. Soedarso Pontianak. Skripsi. Fakultas Kedokteran Universitas Tanjungpura.

Herminawati, A., Suryani, M., \& Sayono. (2008). Perbedaan Lama Rawat Inap Antara Stroke Hemoragik dan Stroke Non Hemoragik Di RSUD Tugurejo Semarang. Skripsi. Universitas Muhammadiyah Semarang

Indonesia, K. K. R. (2018). Riset Kesehatan Dasar. Jakarta.

Kelvin Yuwanda, Ketut Widyastuti, A. A. A. P. L. (2020). Stroke Dengan Gangguan Kognitif Pada Penderita Stroke di RSUP Sanglah, Callosum Neurology, 3, 1-5. https://doi.org/10.29342/cnj.v3i1.10 1
Laily, S. R. (2017). Hubungan Karakteristik Penderita dan Hipertensi dengan Kejadian Stroke Iskemik. Jurnal Berkala Epidemologi, 5(1), 95-106. https://doi.org/10.20473/jbe.v5i1

Mahayani, N. K. D., \& Putra, I. K. (2019). Karakteristik penderita stroke hemoragik di RSUP Sanglah Denpasar. Medicina, 50(1), 210213.https://doi.org/10.15562/medici na.v50i1.481

Pinzon, R. T., \& Hardjito, Y. (2017). Apakah Pemberian Citicolin Dapat Mencegah Luaran Klinis Buruk Pada Pasien Stroke? Farmaka, 15(4), 68-79.

Qureshi, A. I., Adil, M. M., Zacharatos, H., \& K. Suri, M. F. (2013). Factors associated with length of hospitalization in patients admitted with transient ischemic attack in United States. Stroke, 44(6), 16011605.https://doi.org/10.1161/STRO KEAHA.111.000590

Saxena, A., \& Prasad, R. N. (2016). Factors Predicting Length of Hospital Stay in Acute Stroke Patients Admitted in a Rural Tertiary Care Hospital. Journal of Gerontology \& Geriatric Research, 01(s5).https://doi.org/10.4172/21677182.s5-003

Sulistyani, D. O., \& Purhadi. (2013). Analisis Terhadap Faktor-Faktor yang Mempengaruhi Laju Perbaikan Kondisi Klinis Pasien Penderita Stroke dengan Regresi Cox Weibull. Jurnal Sains Dan Seni Pomits, 2(1), 
2337-3520.

Tangkudung G, Pertiwi JM, Girsang R,

Tongku AS3, A. A. (2019).

Characteristic of factors associated with admission time of stroke patients in hospital. Jurnal Sinaps, 2(3), 5-8.

Vijaya Sorganvi, M. S. Kulkarni, Deepak Kadeli, S. A. (2014). Risk factors for stroke: A case control study. Age and Ageing, 6(3), 46-52. https://doi.org/10.1093/ageing/19.5. 280

WHO. (2012). The top 10 causes of death, 2000-2012. Retrieved from http://www.who.int/mediacentre/fac tsheets/fs310/en/ 